\title{
PENGEMBANGAN E-MODUL BERBASIS PROYEK UNTUK MEMOTIVASI BELAJAR SISWA SEKOLAH KEJURUAN
}

\author{
Silvia Oksa ${ }^{1}$ dan Sunaryo Soenarto ${ }^{2}$ \\ ${ }^{1}$ Program Pascasarjana Universitas Negeri Yogyakarta \\ ${ }^{2}$ Fakultas Teknik Universitas Negeri Yogyakarta \\ email: silviaoksa@gmail.com
}

\begin{abstract}
Abstrak
Penelitian ini bertujuan untuk menghasilkan e-modul berbasis proyek yang layak dan efektif untuk meningkatkan motivasi belajar siswa pada Mata Pelajaran Dasar Desain Grafis. Penelitian ini merupakan penelitian dan pengembangan (R\&D) menggunakan model ADDIE (analyze, design, development, implementation, dan evaluation). Proses pengembangan meliputi produksi e-modul, validasi ahli materi dan ahli media, uji coba produk, dan revisi produk. Desain uji coba produk terdiri dari uji coba tahap awal kepada 7 siswa, uji coba lapangan skala kecil kepada 15 siswa, dan uji coba lapangan skala besar dengan melakukan praeksperimental kepada 32 siswa. Instrumen pengumpulan data yang digunakan adalah skala analisis kebutuhan, skala kelayakan e-modul oleh para ahli, skala motivasi belajar, dan skala respons pengguna. Teknik analisis data yang digunakan dalam penelitian ini adalah teknik deskriptif. Hasil penelitian menunjukkan bahwa $e$-modul berbasis proyek yang dihasilkan pada Mata Pelajaran Dasar Desain Grafis sangat layak dan efektif digunakan untuk meningkatkan motivasi belajar siswa SMK pada Mata Pelajaran Dasar Desain Grafis.
\end{abstract} Kata kunci: e-modul, berbasis proyek, dasar desain grafis, motivasi

\section{PROJECT-BASED E-MODULE DEVELOPMENT TO IMPROVE STUDENT LEARNING MOTIVATION OF VOCATIONAL SCHOOL}

\begin{abstract}
This study was aimed at developing a project-based e-module that is feasible and effective to improve student motivation in the Basic Graphic Design subject. This was a research and development research study using ADDIE (Analiyze, Design, Develop, Implement, Evaluation) model. The development process included the production of the e-modules, the validation by material and media experts, product trials, and product revisions. The product trial design consisted of an initial pilot test of 7 students, a small-scale field trial of 15 students, and a large-scale field trial by pre-experimental 32 students. The data collection instruments were the scale of needs analysis, eligibility of the e-modules by experts, learning motivation, and user responses. The data analysis technique was descriptive technique. The results show that the project-based e-module produced is feasible and effective to be used to increase the motivation of vocational student learning in the Basic Graphic Design subjects. Keywords: e-module, project based, basic graphic design, motivation
\end{abstract}

\section{PENDAHULUAN}

Sekolah Menengah Kejuruan (SMK) lebih mengutamakan pengembangan dalam hal kemampuan dan sikap profesional, dan penyiapan peserta didik untuk dapat diterima pada jenis lapangan pekerjaan 
tertentu (Presiden Republik Indonesia, 1990, p. 2). Selain itu, SMK juga menuntut peserta didik untuk memiliki sikap produktivitas yang tinggi agar tercipta standar lulusan yang memiliki kompetensi dan keterampilan. Hal tersebut sejalan dengan tuntutan pembelajaran pada abad 21 saat ini, yang mengintegrasikan kecakapan pengetahuan, keterampilan, dan sikap, serta penguasaan teknologi informasi dan komunikasi dalam proses pembelajaran di sekolah melalui implementasi Kurikulum 2013 revisi 2017.

Struktur Kurikulum 2013 revisi 2017 pada SMK terdiri dari kompetensi inti dan kompetensi dasar (KI-KD) mata pelajaran muatan nasional (A), muatan kewilayahan (B), dasar bidang keahlian (C1), dasar program keahlian (C2), dan kompetensi keahlian (C3) (Direktur Jenderal Pendidikan Dasar dan Menengah, 2017, p. 141-142). Setiap satuan pendidikan kejuruan memiliki beberapa program keahlian, salah satunya Teknik Komputer dan Informatika dengan kompetensi keahlian Rekayasa Perangkat Lunak, Teknik Komputer dan Jaringan, Multimedia, dan Sistem Informatika, Jaringan dan Aplikasi (Direktur Jenderal Pendidikan Dasar dan Menengah, 2017, p. 141-142). SMK Negeri 2 Sewon termasuk yang memiliki kompetensi keahlian multimedia di sekolahnya.

Kompetensi keahlian multimedia menuntut peserta didik untuk dapat menerapkan prinsip seni grafis dan animasi dalam penyajian dan memproduksi produk multimedia. Untuk memenuhi tuntutan tersebut, peserta didik diberikan beberapa mata pelajaran yang sesuai dengan program keahlian maupun kompetensi keahlian yang ditempuh selama belajar di SMK. Salah satu mata pelajaran program keahlian (C2) yang diberikan di SMK Negeri 2 Sewon adalah Dasar Desain Grafis (DDG) merupakan mata pelajaran produktif yang terdiri dari kegiatan belajar teori dan praktik yang ditempuh siswa pada kelas X selama 2 semester atau 1 tahun pembelajaran.

Mata Pelajaran DDG bertujuan untuk mengembangkan pengetahuan dasar dan keterampilan siswa dalam menyampaikan komunikasi visual yang berbasis seni dan teknologi. Proses pembelajaran DDG didukung dengan pemanfaatan teknologi informasi dan komunikasi sehingga mengharuskan siswa untuk dapat mengoperasikan software pembelajaran desain grafis seperti CorelDraw, Photoshop, Ilustrator, dan sebagainya. Salah satu kompetensi dasar Mata Pelajaran DDG yang menggunakan software pembelajaran desain grafis adalah pengolah gambar vektor dengan menggunakan software pembelajaran CorelDraw (Kemendikbud, 2017, p. 130).

Kompetensi dasar pengolah gambar vektor termasuk materi pembelajaran DDG yang membutuhkan pemahaman kognitif terhadap penggunaan fungsi antarmuka (interface), tools, dan fitur pada software pembelajaran CorelDraw dalam melakukan desain grafis. Namun, berdasarkan hasil wawancara bersama guru pengampu Mata Pelajaran DDG diperoleh informasi bahwa ketika kegiatan pembelajaran praktik menggunakan software pembelajaran, kemampuan siswa dalam mengoperasikan software pembelajaran desain grafis masih tergolong rendah, karena siswa yang menempuh mata pelajaran ini belum pernah mendapatkan pembelajaran desain grafis sebelumnya. Selain itu, belum adanya buku, modul maupun lembar kerja siswa (LKS) yang spesifik mengenai Mata Pelajaran DDG yang dapat digunakan.

Pembelajaran DDG dalam Kurikulum 2013 revisi 2017 juga menuntut agar pembelajaran berpusat pada siswa atau student centered yang melibatkan siswa 
secara aktif dan mengarahkan siswa untuk menggali potensi yang mereka miliki. Namun, berdasarkan hasil observasi pada siswa kelas X Multimedia diperoleh informasi bahwa siswa mengeluhkan kesulitan belajar pada kegiatan pembelajaran praktik menggunakan software pembelajaran desain grafis sebab tidak adanya buku, modul maupun LKS yang langsung mengacu pada langkah-langkah mendesain grafis. Hal tersebut menyebabkan pelaksanaan kegiatan pembelajaran praktik siswa hanya berpatokan pada arahan dan instruksi yang diberikan oleh guru sehingga menghambat proses pembelajaran siswa yang memiliki kemampuan tinggi untuk melanjutkan materi pembelajaran berikutnya karena harus menunggu guru memberikan arahan kepada siswa yang memiliki kemampuan rendah.

Rendahnya motivasi belajar siswa terjadi akibat adanya rasa tidak tertarik terhadap materi pembelajaran dan menganggap materi pembelajaran tersebut tidak memiliki manfaat bagi siswa. Kurang tertariknya siswa terhadap materi pembelajaran DDG dikarenakan proses pembelajaran yang berlangsung hanya berpatokan pada penyampaian materi atau instruksi yang diberikan oleh guru. Selain itu, tidak adanya buku, modul maupun LKS yang dapat digunakan siswa untuk berlatih desain grafis pada saat jam pelajaran di sekolah maupun di luar sekolah.

Materi pembelajaran yang disampaikan guru yang tidak menarik perhatian siswa, menimbulkan masalah yang dihadapi berikutnya ialah siswa tidak dapat fokus dalam pembelajaran sehingga hasil belajar dari beberapa siswa pada Mata Pelajaran DDG masih rendah atau dib awah kriteria ketuntasan minimal (KKM) yaitu 75 . Hal tersebut dapat dilihat dari hasil ujian tengah semester (UTS) siswa kelas X Multimedia pada Tahun Ajaran 2017/2018 berikut: presentase ketuntasan siswa kelas X Multimedia 1 sebesar 47,82\% dengan nilai rata-rata sebesar 74,13 ; presentase ketuntasan siswa kelas X Multimedia 2 sebesar $45,45 \%$ dengan nilai rata-rata sebesar 74,32; dan presentase ketuntasan siswa kelas X Multimedia 3 sebesar 50,00\% dengan nilai rata-rata sebesar 77,73.

Kegiatan pembelajaran produktif atau praktik sebaiknya dilakukan dengan menekankan pada proses memberi pengalaman kepada siswa dalam mengintegrasikan pengetahuan awal dengan pengetahuan yang sesuai konsep keilmuan yang dipelajari. Hal tersebut dibuktikan dengan hasil penelitian dari Edgar Dale pada tahun 1969 yang menunjukkan bahwa jika siswa diberi kesempatan melakukan sesuatu dalam pembelajaran (learning by doing) siswa mampu mengingat sebanyak $90 \%$ materi (Warsono \& Hariyanto, 2017, p. 12).

Siswa dikondisikan agar selalu terlibat dalam pengalaman belajar yang bermakna dan senantiasa berpikir, bekerja, serta merasa tentang yang sedang mereka lakukan sehingga terjadinya pembelajaran aktif (Silberman, 2016, p. 116). Pembelajaran aktif dapat diwujudkan melalui pembelajaran kolaboratif, yang memungkinkan siswa untuk mendapatkan pengalaman belajar dalam mengkonstruksi pengetahuan yang dimiliki (DeWitt, Siraj, \& Alias, 2014).

Proses mengintegrasikan pengetahuan awal siswa dengan konsep ilmu yang dipelajari tersebut tentu membutuhkan perantara atau media (channel) agar pesan atau pengetahuan mampu masuk ke dalam pemahaman siswa. Perantara yang dibutuhkan dalam pembelajaran abad 21 ini berupa media pembelajaran yang menarik, efektif, dan efisien dengan memanfaatkan teknologi komputer. Dengan memanfaatkan teknologi komputer sebagai media belajar dapat menciptakan pembelajaran yang 
interaktif, kolaboratif, kreatif, inovatif, dan menyenangkan bagi siswa (Abidin, 2015, p. 97).

Media pembelajaran merupakan segala sesuatu yang digunakan dalam menyalurkan pesan atau informasi serta dapat merangsang pikiran, perhatian, perasaan, dan kemauan siswa sehingga dapat mendorong terjadinya proses pembelajaran yang disengaja, bertujuan, dan terkendali (Miarso, 2009, p. 458). Selain itu, media pembelajaran juga merupakan salah satu perangkat pembelajaran yang memiliki peranan penting dalam proses pembelajaran (Suyantiningsih, Munawaroh, \& Rahmadona, 2016).

Kecanggihan teknologi komputer pada saat ini memungkinkan untuk mendukung terciptanya media pembelajaran berbasis multimedia. Multimedia pembelajaran dapat didefinisikan sebagai kombinasi dari berbagai media yang dikemas secara terpadu dan interaktif dalam menyajikan pesan pembelajaran tertentu (Warsita, 2008 , p. 154). Penggunaan multimedia sebagai bahan ajar interaktif dalam proses pembelajaran dapat menyajikan sebuah materi pembelajaran yang memuat komponen multimedia seperti teks, grafik, gambar, suara, video, dan animasi. Namun, komponen multimedia tersebut harus diolah dan dimanipulasi serta dipadukan secara digital menggunakan perangkat komputer atau peralatan elektronik (Surjono, 2017, p. 2). Hasil penelitian yang dikemukakan oleh Hardiyantari (2017) menunjukkan bahwa penggunaan multimedia pembelajaran berpengaruh dalam proses pembelajaran produktif Teknik Komputer dan Jaringan untuk siswa SMK kelas X dengan hasil peningkatan skor (gain score) rata-rata siswa sebesar 0,71 yang termasuk dalam kategori tinggi.

Multimedia pembelajaran termasuk bahan ajar noncetak yang membutuhkan bantuan komputer untuk menayangkan pesan atau informasi untuk belajar (Prastowo, 2014, p. 42). Salah satu penyajian bahan ajar yang memanfaatkan teknologi audiovisual, berbasis komputer, dan multimedia adalah e-book. Buku elektronik atau biasa dikenal dengan $e$-book merupakan versi elektronik dari buku teks yang dapat dibaca melalui layar desktop atau laptop, atau perangkat portabel lainnya (Educause, 2006, p. 1). Selain itu, Enright (2014, p. 21) juga menyatakan bahwa e-book juga merupakan versi elektronik dari buku akademik, buku teks, buku referensi, monografi ilmiah, dan buku tahunan.

Penyajian bahan ajar yang memanfaatkan teknologi dan multimedia terus berkembang dari waktu ke waktu. Seperti modul pembelajaran cetak yang dapat ditransformasikan ke dalam bentuk elektronik atau digital sehingga disebut modul elektronik (e-modul). E-modul dikembangkan dengan menambahkan beberapa fitur yang spesifik seperti tautan hypertext, fungsi pencarian, dan multimedia (Anuradha \& Usha, 2006). E-modul merupakan suatu bentuk penyajian bahan ajar mandiri yang dirancang untuk membantu siswa dalam mencapai tujuan pembelajaran tertentu yang disusun secara sistematis ke dalam unit pembelajaran terkecil dan disajikan ke dalam format elektronik yang di dalamnya terdapat teks, gambar, audio, video, animasi, dan interaktif (Sugianto, Abdullah, Elvyanti, \& Muladi, 2013). Pengorganisasian materi pembelajaran pada $e$-modul mengacu pada pembuatan urutan materi pembelajaran (squencing), dan mengacu pada keterkaitan fakta, konsep, prosedur, serta prinsip pada materi pembelajaran kepada siswa (synthesizing) (Suyoso \& Nurohman, 2014).

Salah satu model pembelajaran yang dapat mendukung pembelajaran dengan menggunakan multimedia pembelajaran yaitu melalui pembelajaran berbasis proyek 
(project-based learning). Pembelajaran berbasis proyek merupakan suatu pengajaran yang mengaitkan antara teknologi dengan masalah kehidupan sehari-hari yang akrab dengan siswa, atau dengan suatu proyek sekolah (Warsono \& Hariyanto, 2017, p. 153). Dalam proses pembelajaran berbasis proyek siswa akan merancang, melakukan pemecahan masalah, melaksankan pengambilan keputusan, dan kegiatan penyelidikan sendiri dalam membuat sebuah proyek. Hasil akhir proyek tersebut berupa artefak yang meliputi karya ilmiah, suatu model, film, video, CD, DVD, dan lain sebagainya.

Sesuai dengan karakteristik Mata Pelajaran DDG yang merupakan pembelajaran produktif atau praktik dalam memahami konsep dan prinsip-prinsip desain grafis. Strategi pembelajaran yang tepat untuk digunakan dalam penggunaan multimedia pembelajaran DDG adalah dengan menggunakan model pembelajaran berbasis proyek. Hal tersebut didukung oleh Atef dan Medhat (2015) dalam penelitiannya yang menyatakan bahwa lingkungan pembelajaran Desain Grafis lebih efektif dilaksanakan atas dasar pembelajaran berbasis proyek. Selain itu, model pembelajaran ini diperlukan dalam pembelajaran DDG, karena dapat meningkatkan metakognitif siswa dalam memahami konsep dan prinsip desain grafis melalui pengalaman siswa sendiri dalam menciptakan produk.

Hal tersebut dibuktikan melalui hasil penelitian yang dilakukan oleh Herawati dan Muhtadi (2018) yang menunjukkan bahwa penggunaan modul elektronik (e-modul) dalam proses pembelajaran asam basa pada Mata Pelajaran Kimia efektif untuk digunakan sebagai media pembelajaran siswa dalam meningkatkan hasil belajar siswa kelas XI IPA SMA Islam Al-Azhar Yogyakarta dengan presentase peningkatan jumlah ketuntasan siswa sebesar 75,80\%. Selain itu, didukung juga dengan pernyataan yang dikemukakan oleh Warsita (2008, p. 137) bahwa media pembelajaran berbantuan komputer (Computer Assisted Instructional/CAI) menjadi salah satu media pembelajaran yang sangat menarik dan mampu meningkatkan motivasi belajar siswa.

Surjono (2017, p. 5) menambahkan bahwa salah satu cara meningkatkan motivasi belajar siswa dengan menggunakan multimedia adalah dengan memberikan multimedia yang interaktif sehingga memberi kesempatan siswa untuk beraktivitas. Selain meningkatkan motivasi belajar, melalui media pembelajaran dapat memberikan kemudahan bagi siswa untuk mempelajari materi pembelajaran sehingga meningkatkan hasil belajar yang lebih baik (Maswan \& Muslimin, 2017, p. 121).

Penelitian ini bertujuan untuk mengetahui kelayakan e-modul berbasis proyek yang dihasilkan, dan mengetahui keefektifan $e$-modul berbasis proyek terhadap motivasi belajar siswa sekolah kejuruan.

\section{METODE}

Metode penelitian yang digunakan adalah penelitian dan pengembangan atau dikenal dengan istilah R\&D (Research and Development). Desain penelitian dan pengembangan yang dikembangkan dalam penelitian ini mengadopsi dari model ADDIE yang meliputi lima tahapan. Pertama, Analyze (analisis). Menganalisis kebutuhan, situasi dan kondisi siswa, guru, serta sumber belajar yang sesuai dengan karakteristik siswa dalam proses pembelajaran dengan melakukan penelitian tahap awal dan mengumpulkan data. Kedua, Design (desain). Produk e-modul Mata Pelajaran DDG didesain secara sistematis berdasarkan analisis desain instruksional. 
Ketiga, Develop (pengembangan). Merealisasikan rancangan produk sebuah e-modul pada Mata Pelajaran DDG yang telah dibuat. Keempat, Implement (implementasi). Melakukan uji coba produk e-modul kepada ahli materi, ahli media, dan pengguna. Kelima, Evaluate (evaluasi). Melakukan penilaian e-modul melalui respons siswa terhadap penggunaan $e$-modul kemudian dilakukan revisi produk.

Uji coba produk melibatkan 54 siswa kelas X di SMK Negeri 2 Sewon. Teknik pengumpulan data yang digunakan berupa observasi, wawancara, dan skala untuk mengetahui tingkat motivasi belajar siswa dan respons siswa terhadap media yang digunakan untuk meningkatkan pemahaman siswa.

Teknik analisis data yang digunakan dalam penelitian ini adalah teknik analisis deskriptif kuantitatif, yaitu memaparkan hasil pengembangan produk e-modul setelah diimplementasikan, dilakukan validasi dan kelayakan produk. Skala pengukuran untuk menentukan kategori kelayakan dari produk adalah dengan skala likert dengan skala 5. Tabel klasifikasi disusun menggunakan rumus (1) yaitu aturan yang sama dengan dasar jumlah skor responden, yaitu mencari skor tertinggi, skor terendah, jumlah kelas, dan jarak interval (Widoyoko, 2017, p. 11). Skor tertinggi $=5$ (sangat layak) Skor terendah $=1$ (sangat kurang layak) Jumlah kelas $=5$

Jarak interval $=\frac{\text { skor tertinggi }- \text { skor terendah }}{\text { jumlah } \text { kelas interval }}$ (1)

Hasil perhitungan diperoleh jarak intervalnya 0,8 . Berdasarkan data tersebut disusun Tabel 1 yang menyajikan klasifikasi kategori media pembelajaran e-modul berbasis proyek yang dihasilkan.

Data yang diperoleh melalui skala motivasi belajar siswa yang berupa nilai
Tabel 1

Klasifikasi Skor Penilaian Produk

\begin{tabular}{cl}
\hline $\begin{array}{c}\text { Rerata Skor } \\
\text { Jawaban }\end{array}$ & \multicolumn{1}{c}{ Klasifikasi } \\
\hline $\bar{X}>4,2-5,0$ & Sangat Layak \\
$\bar{X}>3,4-4,2$ & Layak \\
$\bar{X}>2,6-3,4$ & Cukup Layak \\
$\bar{X}>1,8-2,6$ & Kurang Layak \\
$\bar{X}>1,0-1,8$ & Sangat Kurang Layak \\
\hline
\end{tabular}

Keterangan: $\bar{X}:$ rerata skor yang diperoleh

kuantitatif diubah menjadi nilai kualitatif. Setelah data diubah menjadi data kualitatif, selanjutnya dianalisis untuk mengetahui keefektifan penggunaan $e$-modul berbasis proyek dalam meningkatkan motivasi belajar siswa. Nilai akhir (NA) dari penggabungan hasil pernyataan tersebut menurut Uno (2017, p. 23) disajikan pada rumus (2). Keterangan kriteria nilai disajikan pada Tabel 2.

$N A=\frac{\sum \text { skor responden }}{\sum \text { skor maksimal pernyataan }} \times 100 \%$

Data dari hasil motivasi belajar siswa dianalisis menggunakan rumus standard gain (g) (3) untuk mengetahui peningkatan motivasi belajar siswa. Interpretasi nilai standard gain (g) disajikan dalam kriteria pada Tabel 3.

$$
g=\frac{\text { skor akhir }- \text { skor awal }}{\text { skor maksimum }- \text { skor awal }}(3)
$$

Tabel 3

Interpretasi Nilai Standard Gain (g)

\begin{tabular}{ll}
\hline \multicolumn{1}{c}{ Nilai $g$} & \multicolumn{1}{c}{ Kriteria } \\
\hline$g \geq 0,7$ & Tinggi (Sangat Efektif) \\
$0,7>g \geq 0,3$ & Sedang (Efektif) \\
$g<0,3$ & Rendah (Tidak Efektif) \\
\hline
\end{tabular}

HASIL PENELITIAN DAN PEMBAHASAN

Proses penelitian dilakukan pada siswa kelas X SMK kompetensi keahlian Multimedia yang menempuh Mata 
Tabel 2

Kriteria Penilaian Motivasi

\begin{tabular}{lll}
\hline \multicolumn{1}{c}{ Rentang Skor (i) } & \multicolumn{1}{c}{ Nilai } & \multicolumn{1}{c}{$\begin{array}{c}\text { Kategori } \\
\text { (Tingkat Motivasi) }\end{array}$} \\
\hline$X \geq \bar{X}+\mathbf{1 S} B_{x}$ & $X \geq 90$ & Sangat Tinggi \\
$\bar{X}+1 S B_{x}>X \geq \bar{X}$ & $90>X \geq 75$ & Tinggi \\
$\bar{X}>X \geq \bar{X}-1 S B_{x}$ & $75>X \geq 60$ & Rendah \\
$X<\bar{X}-\mathbf{1 S} B_{x}$ & $X<60$ & Sangat Rendah \\
\hline
\end{tabular}

$$
\begin{aligned}
& \text { Keterangan: } \\
& \bar{X}= \text { rerata skor ideal } \\
&= \frac{1}{2}(\text { skor maksimum }+ \text { skor minimum }) \\
& S B_{x}= \text { simpangan baku skor ideal } \\
& \frac{1}{6}(\text { skor maksimum }- \text { skor minimum }) \\
& X \quad= \text { skor yang diperoleh siswa }
\end{aligned}
$$

Pelajaran DDG. Kegiatan pengembangan dilakukan untuk menghasilkan sebuah produk e-modul pembelajaran DDG dengan berdasarkan pada tahapan model pengembangan ADDIE. Dalam penelitian ini tahap yang pertama kali dilakukan adalah analisis kebutuhan dan selanjutnya mengumpulkan data. Kebutuhan siswa terhadap sumber belajar disajikan pada Gambar 1. Skala kebutuhan siswa dalam pembelajaran DDG membuktikan bahwa sebanyak $100 \%$ siswa menginginkan sumber belajar yang dapat digunakan dalam pembelajaran DDG dengan rincian sebagai berikut: $14,93 \%$ siswa menginginkan buku panduan; $4,48 \%$ siswa menginginkan modul cetak; dan $80,60 \%$ siswa menginginkan e-modul berbasis proyek sebagai sumber belajar yang digunakan dalam proses pembelajaran DDG. Selain itu, siswa juga menginginkan sumber belajar yang memuat video tutorial.

Untuk melengkapi data pada tahap analisis juga dilakukan analisis dokumen dan studi pustaka yang terkait: silabus Mata Pelajaran DDG, studi pustaka mengenai

Gambar 1. Grafik Jenis Sumber belajar

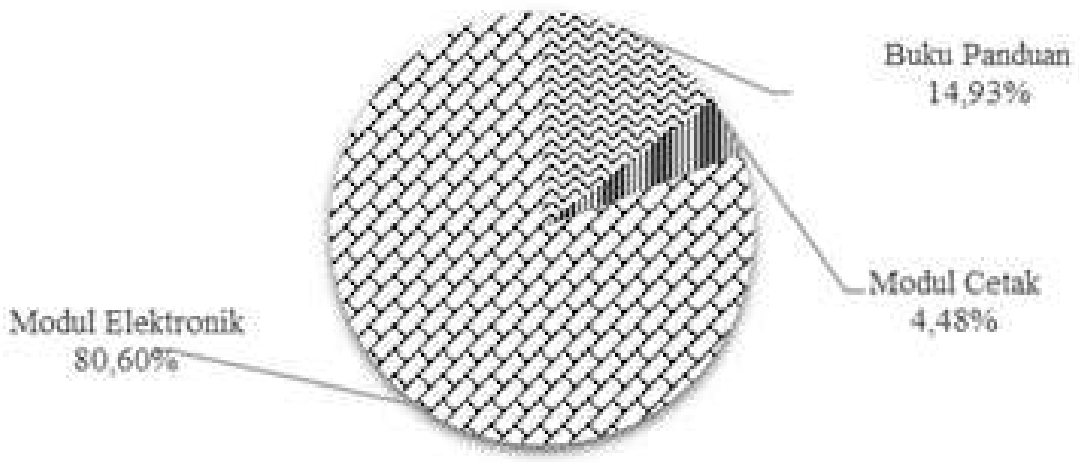


materi-materi yang berkaitan dengan DDG khususnya materi Pengolah Gambar Vektor, dan melakukan brainstorming dengan guru Mata Pelajaran DDG untuk merumuskan capaian pembelajaran e-modul.

Analisis desain instruksional produk $e$-modul berbasis proyek ini dikembangkan secara sistematis dengan mengadopsi model pengembangan instruksional Atwi Suparman. Pada penelitian ini hanya menggunakan dua tahap yaitu tahap mengidentifikasi dan mengembangkan. Rencana pelaksanaan pembelajaran (RPP) dikembangkan berdasarkan silabus Mata Pelajaran DDG untuk mengarahkan proses pembelajaran dalam mencapai kompetensi dasar yang telah ditetapkan.

Storyboard yang dikembangkan merupakan rancangan detail dari gambaran produk yang terdiri atas rancangan tampilan baik itu tema, tombol/navigasi, warna, dan komponen multimedia, serta pemrograman yang akan ditampilkan pada produk e-modul.

Produk e-modul berbasis proyek dikembangkan untuk siswa kelas $\mathrm{X}$ kompetensi keahlian Multimedia dalam format file pdf yang dikonversi ke dalam format exe menggunakan software Flip PDF Professional. Pengembangan konten produk e-modul menggunakan beberapa komponen multimedia seperti teks, gambar, video, dan interaktif yang digabungkan menjadi sebuah file digital.

Adapun tahapan-tahapan yang dilakukan dalam mengembangkan e-modul adalah sebagai berikut. Pertama, menyiapkan teks materi yang disusun berdasarkan kompetensi inti, kompetensi dasar, dan indikator pencapaian kompetensi yang harus dicapai siswa pada Mata Pelajaran DDG. Kedua, membuat grafis seperti halaman sampul, cover setiap kegiatan belajar, header-footer, dan highlight dibuat menggunakan software CorelDRAW X7. Ketiga, melakukan rekaman video tutorial pada kegiatan praktik setiap kegiatan belajar dilakukan dengan menggunakan software Camtasia 9 dan proses pengeditan video juga dilakukan menggunakan software tersebut. Keempat, membuat kuis interaktif sebagai tes formatif dan tes akhir dibuat menggunakan Adobe Flash CS6 dengan jumlah 20 soal objektif (pilihan ganda) untuk tes formatif dan 40 soal untuk tes akhir. Kelima, menggabungkan file digital berupa komponen multimedia menggunakan Nitro Pro 8 sehingga file yang dihasilkan dalam format .pdf. Selanjutnya, menggabungkan file pdf dengan komponen multimedia lain seperti video dan kuis interaktif menggunakan Flip PDF Professional sehingga hasil akhir produk e-modul dalam format file .exe dan dikemas dalam bentuk compact disk (CD).

Tahap implementasi produk dilakukan melalui pelaksanaan uji coba tahap awal, uji coba lapangan skala kecil, dan uji coba lapangan skala besar. Namun, sebelum melakukan uji coba produk ke pengguna, e-modul terlebih dahulu dilakukan uji kelayakan melalui validasi ahli materi dan ahli media. Validasi dilakukan dengan tujuan untuk memperoleh saran dan komentar dari ahli materi dan ahli media terhadap produk yang dikembangkan sehingga dapat menghasilkan produk yang layak untuk digunakan dalam proses pembelajaran.

Validasi materi pada pengembangan produke-modul berbasis proyek ini dilakukan oleh dua orang ahli materi. Validasi materi dilakukan dengan menggunakan skala kelayakan materi pada $e$-modul yang terdiri dari aspek pendahuluan, pembelajaran, isi, rangkuman, dan tugas/evaluasi. Hasil validasi ahli materi disajikan pada Tabel 4. Setelah dilakukan proses validasi dan diskusi bersama ahli materi, dilakukan revisi produk sehingga materi pada produk $e$-modul berbasis proyek dinyatakan layak dan dapat digunakan dalam pembelajaran. 
Tabel 4

Hasil Validasi Ahli Materi

\begin{tabular}{|c|c|c|c|c|}
\hline \multirow{2}{*}{ Aspek Penilaian } & \multicolumn{2}{|c|}{ Ahli Materi } & \multirow{2}{*}{ Jumlah } & \multirow{2}{*}{ Rerata Skor } \\
\hline & 1 & 2 & & \\
\hline Pendahuluan & 4,6 & 4,4 & 9,0 & 4,5 \\
\hline Pembelajaran & 4,4 & 4,6 & 9,0 & 4,5 \\
\hline Isi & 4,5 & 4,1 & 8,6 & 4,3 \\
\hline Rangkuman & 4,5 & 4,8 & 9,3 & 4,6 \\
\hline Tugas/ Evaluasi & 4,2 & 4,5 & 8,7 & 4,3 \\
\hline Jumlah Keseluruhan & & & 44,5 & \\
\hline Rerata Skor Keseluruhan & & & & 4,5 \\
\hline Kategori & & & San & t Layak \\
\hline
\end{tabular}

Validasi media pada pengembangan produk e-modul berbasis proyek ini juga dilakukan oleh dua orang ahli media. Validasi media dilakukan dengan menggunakan skala kelayakan media e-modul yang terdiri dari aspek pendahuluan, tampilan program, pemanfaatan, dan prinsip desain multimedia. Hasil validasi ahli media disajikan pada Tabel 5. Setelah dilakukan proses validasi serta diskusi bersama ahli media dan selanjutnya dilakukan revisi produk sehingga produk $e$-modul berbasis proyek dinyatakan layak dan dapat digunakan dalam pembelajaran.

Uji coba produk dilakukan kepada pengguna yaitu siswa kelas X Multimedia di SMK Negeri 2 Sewon. Uji coba produk dilaksanakan melalui tiga tahap yaitu uji coba tahap awal, lapangan utama, dan lapangan operasional dengan melakukan uji praeksperimental. Uji coba produk dilakukan untuk mengetahui keefektifan penggunaan $e$-modul dalam meningkatkan motivasi belajar siswa pada mata pelajaran Dasar Desain Grafis melalui skala respons pengguna dan pretest-posttest.

Uji coba produk pada tahap pertama yaitu uji coba tahap awal dengan melibatkan tujuh orang siswa kelas X Multimedia 1 yang dipilih secara acak. Penilaian terdiri dari aspek pendahuluan, tampilan program, isi/uraian materi, dan tugas/latihan. Tabel 6 menyajikan hasil uji coba tahap awal. Selanjutnya dilakukan revisi produk sesuai saran yang diberikan sehingga produk

Tabel 5

Hasil Validasi Ahli Media

\begin{tabular}{lcccc}
\hline \multirow{2}{*}{\multicolumn{1}{c}{ Aspek Penilaian }} & \multicolumn{2}{c}{ Ahli Media } & \multirow{2}{*}{ Jumlah } & $\begin{array}{c}\text { Rerata } \\
\text { Skor }\end{array}$ \\
\cline { 2 - 3 } & 1 & 2 & & 4,6 \\
Pendahuluan & 4,4 & 4,8 & 9,1 & 4,7 \\
Tampilan Program & 4,5 & 4,9 & 9,5 & 4,4 \\
Pemanfaatan & 4,3 & 4,6 & 8,9 & 4,6 \\
Prinsip Desain Multimedia & 4,5 & 4,8 & 9,3 & 4,6 \\
\hline Jumlah Keseluruhan & & & 36,7 & \multicolumn{3}{c}{ Sangat Layak } \\
\hline Rerata Skor Keseluruhan & & & \multicolumn{3}{c}{} \\
\hline Kategori & & \multicolumn{4}{c}{} \\
\hline
\end{tabular}


Tabel 6

\begin{tabular}{|c|c|c|}
\hline No & Aspek Penilaian & Rerata Skor \\
\hline 1 & Pendahuluan & 3,8 \\
\hline 2 & Tampilan Program & 3,9 \\
\hline 3 & Isi/Uraian Materi & 3,9 \\
\hline \multirow[t]{3}{*}{4} & Tugas/Latihan & 4,1 \\
\hline & Rerata Skor Keseluruhan & 3,9 \\
\hline & Kategori & Layak \\
\hline
\end{tabular}

e-modul berbasis proyek dinyatakan layak dan dapat digunakan dalam pembelajaran.

Uji coba produk pada tahap kedua yaitu uji coba lapangan skala kecil dengan melibatkan 15 orang siswa kelas $\mathrm{X}$ Multimedia 1 yang dipilih secara acak. Penilaian terdiri dari aspek pendahuluan, tampilan program, isi/uraian materi, dan tugas/latihan. Hasil uji coba lapangan skala kecil dapat dilihat pada Tabel 7. Setelah dilakukan uji coba lapangan skala kecil kepada pengguna, produk e-modul berbasis proyek dinyatakan layak dan dapat digunakan dalam pembelajaran.

Uji coba lapangan skala besar dengan melibatkan seluruh siswa kelas $\mathrm{X}$ Multimedia 2 dengan jumlah 32 siswa. Uji coba produk pada tahap ini dilakukan melalui uji praeksperimental dengan tujuan untuk mengetahui keefektifan penggunaan $e$-modul berbasis proyek dalam meningkatkan motivasi siswa kelas
X Multimedia SMK Negeri 2 Sewon pada Mata Pelajaran DDG. Pengukuran motivasi belajar siswa dilakukan pada saat sebelum dan sesudah pelaksanaan pembelajaran DDG menggunakan e-modul berbasis proyek. Deskripsi hasil motivasi belajar siswa sebelum dan sesudah pelaksanaan pembelajaran menggunakan e-modul berbasis proyek dapat dilihat pada Tabel 8.

Perbandingan skor rata-rata nilai akhir peningkatan motivasi belajar siswa pada pembelajaran DDG dapat dilihat pada Tabel 9. Peningkatan motivasi belajar siswa dapat diketahui bahwa siswa yang memiliki motivasi belajar dengan kategori sangat tinggi bertambah 1 orang atau meningkat sebesar $3,13 \%$; siswa yang memiliki motivasi belajar dengan kategori tinggi bertambah 17 orang atau meningkat sebesar $53,12 \%$; dan siswa yang memiliki motivasi belajar dengan kategori rendah

Tabel 7

\begin{tabular}{|c|c|c|}
\hline No & Aspek Penilaian & Rerata Skor \\
\hline 1 & Pendahuluan & 4,3 \\
\hline 2 & Tampilan Program & 4,3 \\
\hline 3 & Isi/Uraian Materi & 4,3 \\
\hline \multirow[t]{3}{*}{4} & Tugas/Latihan & 4,4 \\
\hline & Rerata Skor Keseluruhan & 4,3 \\
\hline & Kategori & Sangat Layak \\
\hline
\end{tabular}


Tabel 8

Nilai Motivasi Belajar Siswa Sebelum dan Sesudah Pelaksanaan

Pembelajaran Menggunakan E-modul Berbasis Projek

\begin{tabular}{lccc}
\hline \multicolumn{1}{c}{ Deskripsi } & Sebelum & Sesudah & $N$-Gain \\
\hline Nilai Tertinggi & 80,00 & 93,33 & 77,78 \\
Nilai Terendah & 70,00 & 70,00 & 0 \\
Nilai Akhir & 74,82 & 85,03 & 40,53 \\
Rata-Rata & 3,0 & 3,4 & \\
\hline
\end{tabular}

Tabel 9

Frekuensi Motivasi Belajar Siswa Sebelum dan Sesudah Pelaksanaan Pembelajaran Menggunakan E-modul Berbasis Projek

\begin{tabular}{lccccc}
\hline \multirow{2}{*}{ Kategori } & \multicolumn{2}{c}{ Sebelum } & \multicolumn{2}{c}{ Sesudah } & \multirow{2}{*}{ gain } \\
\cline { 2 - 5 } & $\mathrm{f}$ & $\%$ & $\mathrm{f}$ & $\%$ & \\
\hline Sangat Tinggi & 0 & 0 & 1 & 3,13 & 3,13 \\
Tinggi & 11 & 34,38 & 28 & 87,50 & 53,12 \\
Rendah & 21 & 65,63 & 3 & 9,38 & 56,25 \\
Sangat Rendah & 0 & 0 & 0 & 0 & 0 \\
\hline Total & 32 & 100 & 32 & 100 & \\
\hline
\end{tabular}

berkurang 18 orang atau menurun sebesar $56,25 \%$. Setelah dilakukan analisis lebih dalam, terdapat 1 siswa yang peningkatan motivasi belajarnya dari kategori rendah menjadi kategori sangat tinggi, kemudian 17 siswa yang peningkatan motivasi belajarnya dari kategori rendah menjadi kategori tinggi. Namun, juga terdapat beberapa siswa yang tidak mengalami peningkatan motivasi belajar yaitu 11 siswa yang motivasi belajarnya tetap tinggi dan 3 siswa yang motivasi belajarnya tetap rendah.

Media pembelajaran e-modul berbasis proyek efektif digunakan sebagai sumber belajar untuk mendukung proses pembelajaran DDG baik teori maupun praktik (produktif). Pembelajaran dengan menggunakan e-modul berbasis proyek dapat dilaksanakan secara mandiri maupun tatap muka sehingga siswa dapat menambah pengetahuan dan keterampilan dalam desain grafis kapan saja dan di mana saja.

Setelah pelaksanaan pembelajaran menggunakan e-modul dengan melibatkan seluruh siswa kelas X Multimedia 2, kemudian siswa diberikan skala respons pengguna. Pemberian skala dilakukan untuk mengetahui respons siswa terhadap e-modul yang terdiri dari aspek pendahuluan, tampilan program, isi/uraian materi, dan tugas/latihan. Distribusi frekuensi hasil uji coba lapangan skala besar disajikan pada Tabel 10.

Setelah dilakukan uji coba lapangan skala besar kepada pengguna melalui uji praeksperimental, produk e-modul berbasis proyek dinyatakan efektif digunakan sebagai sumber belajar pendukung untuk meningkatkan motivasi belajar siswa kelas X SMK kompetensi keahlian Multimedia pada Mata Pelajaran DDG. 
Tabel 10

Hasil Uji Coba Lapangan Skala Besar

\begin{tabular}{clc}
\hline No & \multicolumn{1}{c}{ Aspek Penilaian } & Rerata Skor \\
\hline 1 & Pendahuluan & 4,3 \\
2 & Tampilan Program & 4,4 \\
3 & Isi/Uraian Materi & 4,4 \\
4 & Tugas/Latihan & 4,4 \\
\hline & Rerata Skor Keseluruhan & 4,4 \\
\hline & Kategori & Sangat Layak \\
\hline
\end{tabular}

\section{SIMPULAN}

Berdasarkan hasil penelitian dan pengembangan produk e-modul berbasis proyek dapat disimpulkan sebagai berikut. Pertama, produk e-modul berbasis proyek pada Mata Pelajaran DDG untuk siswa Kelas X Multimedia telah diuji kelayakannya berdasarkan penilaian para ahli. Pada aspek materi memperoleh rerata skor sebesar 4,5. Nilai tersebut tergolong dalam kategori sangat layak. Kelayakan produk e-modul pada aspek media memperoleh rerata skor sebesar 4,6. Nilai tersebut tergolong dalam kategori sangat layak. Kelayakan produk e-modul pada aspek respons pengguna melalui uji coba tahap awal, produk e-modul tergolong dalam kategori layak. Pada uji coba lapangan skala kecil dan lapangan operasional hasil respons pengguna menunjukkan produk e-modul tergolong dalam kategori sangat layak.

Kedua, keefektifan produk e-modul berbasis proyek dalam meningkatkan motivasi belajar siswa dilihat dari skor rata-rata nilai akhir motivasi belajar siswa pada saat sebelum menggunakan $e$-modul sebesar 74,82 dengan kategori rendah. Pada saat sesudah menggunakan e-modul sebesar 85,03 dengan kategori tinggi. Nilai akhir motivasi belajar tersebut mengalami peningkatan sebesar 0,4 . Skor tersebut tergolong dalam kategori sedang sehingga dapat dinyatakan bahwa penggunaan produk e-modul efektif untuk digunakan dalam meningkatkan motivasi belajar siswa kelas X Multimedia SMK Negeri 2 Sewon pada Mata Pelajaran DDG.

\section{DAFTAR PUSTAKA}

Abidin, Y. (2015). Pembelajaran multiliterasi: Sebuah jawaban atas tantangan pendidikan abad ke-21 dalam konteks keindonesiaan. Bandung: Refika Aditama.

Anuradha, K. T., \& Usha, H. S. (2006). Use of e-book in an academic and research environment: A case study from the Indian institute of science. Journal of Electronic Library and Information Systems, 40(1), 48-62.

Atef, H., \& Medhat, M. (2015). Blended learning possibilities in enhancing education, training and development in developing countries: A case study in graphic design courses. Journal of Technology Education Management Informatics, 4(4), 358-365

Direktur Jenderal Pendidikan Dasar dan Menengah. (2017). Surat Keputusan Direktur Jenderal Pendidikan Dasar dan Menengah Nomor: 330/D. D5/KEP/KR/2017. Jakarta: Ditjen Pendidikan Dasar dan Menengah.

DeWitt, D., Siraj, S., \& Alias, N. (2014). Collaborative mLearning: A module 
for learning secondary school science. Journal of Educational Technology and Society, 17(1), 89-101.

Educause. (2006). 7 things you should know about e-books. Educause Learning Initiative. Diunduh dari https://library.educause.edu/-/media/ files/library/2006/11/eli7020-pdf.pdf.

Enright, S. (2014). Ebooks: the learning and teaching perspective. Dalam $\mathrm{H}$. Woodward (Ed.) Ebooks in education: Realising the vision (pp. 21-33). London: Ubiquity Press.

Hardiyantari, O. (2017). Pengembangan multimedia pembelajaran interaktif menggunakan teknik dinamis pada mata pelajaran produktif teknik komputer dan jaringan untuk siswa SMK kelas X. Jurnal Inovasi Teknologi Pendidikan, 4(1), 77-83.

Herawati, N. S., \& Muhtadi, A. (2018). Pengembangan modul elektronik (e-modul) interaktif pada Mata Pelajaran Kimia kelas X SMA. Jurnal Inovasi Teknologi Pendidikan, 5(2), 180-191.

Kemendikbud. (2017). Kompetensi inti dan kompetensi dasar SMK/MAK kompetensi keahlian multimedia. Jakarta: Direktorat PSMK Direktorat Jenderal Pendidikan dan Menengah.

Maswan, \& Muslimin, K. (2017). Teknologi pendidikan: Penerapan pembelajaran yang sistematis. Yogyakarta: Pustaka Pelajar.

Miarso, Y.(2009). Menyemai benih teknologi pendidikan. Jakarta: Kencana.

Prastowo, A. (2014). Panduan kreatif membuat bahan ajar inovatif: menciptakan metode pembelajaran yang menarik dan menyenangkan. Yogyakarta: Diva Press.
Presiden Republik Indonesia. (1990). Peraturan Pemerintah RI Nomor 29 Tahun 1990 tentang Pendidikan Menengah. Jakarta.

Silberman, M. L. (2016). Active learning: 101 cara belajar siswa aktif. (Terj.: Raisul Muttaqien). Bandung: Nuansa Cendekia. (Edisi asli diterbitkan tahun 1996 oleh Allyn and Bacon, Boston).

Sugianto, D., Abdullah, A. G., Elvyanti, S., \& Muladi, Y. (2013). Modul virtual: Multimedia flipbook dasar teknik digital. Jurnal Innovation of Vocational Technology Education, 9(2), 101-116.

Surjono, H. D. (2017). Multimedia pembelajaran interaktif: Konsep dan pengembangan. Yogyakarta: UNY Press.

Suyantiningsih, Munawaroh, I., \& Rahmadona, S. (2016). Pengembangan multimedia pembelajaran berbasis scientific approach terintegrasi nilai karakter. Jurnal Kependidikan, 46(1), $1-13$.

Suyoso, \& Nurohman, S. (2014). Pengembangan modul elektronik berbasis web sebagai media pembelajaran fisika. Jurnal Kependidikan, 44(1), 73-82.

Uno, H. B. (2017). Teori motivasi dan pengukurannya: Analisis di bidang pendidikan. Jakarta: Bumi Aksara.

Warsita, B. (2008). Teknologi pembelajaran: Landasan dan aplikasinya. Jakarta: Rineka Cipta.

Warsono, \& Hariyanto. (2017). Pembelajaran aktif. Bandung: Remaja Rosdakarya.

Widoyoko, E. P. (2017). Teknik penyusunan instrumen penelitian. Yogyakarta: Pustaka Pelajar. 